\title{
ANALYSIS THE USE OF SOCIAL MEDIA ON PURCHASE DECISIONS
}

Submitted Date :

27 Oktober 2020

Accepted Date :

23 Desember 2020
Rahmat Alfikri

Sekolah Tinggi llmu Ekonomi Boedi Oetomo ubnorm.co@gmail.com

Dwiyadi Surya Wardana

Sekolah Tinggi llmu Ekonomi Boedi Oetomo

vcosjak@gmail.com

\section{Suggested Citation:}

As'ad, H. A dan Anas Y. A, 2014 "The Impact of Social Media Marketing on Brand Equity: An Empirical Study on Mobile Service Providers in Jordan", Society of Interdisciplinary Business Research, Vol 3 No.1, 315-326.

Abstract:

The purpose of this research is to analyze the extent to which social media users influence purchasing decisions in small and medium enterprises in the city of Pontianak with marketing dimensions in the form of Online Communities, Interaction, Content Sharing, Accessibility, Credibility on purchasing decisions through social media. SME consumers in Pontianak were taken as respondents. This research uses an accidental simple random sampling technique; the number of respondents collected, 100 respondents. Data analysis using Structural Equation Modelling (SEM). The results showed that the marketing dimension had a direct effect on purchasing decisions through social media. Suggestions in this study are for business people to be more creative and innovative in making new strategies, so as to create and influence purchasing decisions.

Keywords: Marketing, Social Media, and Purchasing Decisions.

Abstrak :

Tujuan dari penelitian ini adalah untuk menganalisis sejauh mana pengaruh pengguna media sosial terhadap keputusan pembelian pada usaha kecil dan menengah di Kota Pontianak dengan dimensi pemasaran berupa Komunitas Online, Interaksi, Berbagi Konten, Aksesibilitas, dan Kredibilitas terhadap keputusan pembelian melalui media sosial. Penelitian ini menggunakan teknik accidental simple random sampling dan jumlah responden yang dikumpulkan adalah 100 responden. Analisis data menggunakan Structural Equation Modeling (SEM). Hasil penelitian menunjukkan bahwa dimensi pemasaran berpengaruh langsung terhadap keputusan pembelian melalui media sosial. Saran dalam penelitian ini adalah agar para pelaku bisnis lebih kreatif dan inovatif dalam membuat strategi baru, sehingga mampu menciptakan dan mempengaruhi keputusan pembelian.

JEL Classification: M31 


\section{Research Background}

With advances in technology, the use of media as a means of presenting and receiving information is a great potential for business actors to market their products to consumers so that they can attract consumers online. SMEs is a term used in the type of small business, which according to Presidential Decree no. 99 of 1998, Small Business is a small of scale economic activity of the people with a business sector which is a small business activity. The technology of the presence of applications such as social media that can provide information and meet consumer needs, especially in big cities, one of which is Pontianak. By only using social media, consumers can determine and make purchases to make it easier for consumers and give time, consumers no longer need to look for what they want, simply by using social media consumers can determine the desired goods or services, consumers can also obtain information through content listed or directly from the seller.

The use of social media as a tool to provide and receive information is a big potential for SMEs to market their products to consumers, Dwianto, Iqbal, and Alfisyah, (2018), online social media such as Facebook, Instagram, YouTube, Twitter, and others. changing a consumer's lifestyle. Social media applications that share photos or images that look strong in influencing consumer purchase interest, not only in the form of text but consumers can also obtain information through images posted by Indika and Jovita, (2017). Therefore, to influence purchasing decisions which is an action based on meeting consumer needs, where the use of social media is currently not only used as a tool of necessity, but is used as a tool to introduce the potential of business actors and their products to consumers, which is Pudjihardjo and Wijaya, (2015) concluded that online purchasing decisions are seen from the influence of the dimensions of trust, information quality, and product appearance.

Internet users in Indonesia, according to research on social media management platforms in 2019, have instant messaging application penetration of $100 \%$, while interactions on social media applications contribute 92\%. Based on We Are Social entitled Global Digital Reports 2020, there are 175.4 million internet users and an increase of $17 \%$ or 25 million internet users in Indonesia. $88 \%$ of social media application users access Youtube, then WhatsApp $84 \%$, Facebook $82 \%$, and Instagram $79 \%$, while reports of the statement that $65 \%$ of social media users in Indonesia use social media for work in general can be seen in the table below:

Table 1. Most-used social media platforms

\begin{tabular}{cccc} 
Youtube & FaceBook & WhatsApp & Instragram \\
\hline $88 \%$ & $84 \%$ & $82 \%$ & $79 \%$ \\
\hline
\end{tabular}

Source: Hootsuite (We are Social): Indonesian Digital Report 2020

From these data it can be stated that social media brings new ways in communication in social life and it is very important to be used as an optimization of marketing strategy formulation. Reasons for using social media to run a business, namely, marketing strategy, external and internal marketing communication media, cost factors, ease of use, use of social media, Wulandari and Supratman, (2018). The use of social media can be used as a strategic plan for SMEs in marketing their products in order to survive and face competition, Moriansyah (2015), is known to further optimize marketing through social media, motivation or reason. marketers and the results that can be achieved through social media marketing must be able to apply, to develop other marketing strategies. This is deemed necessary because many business actors fail because they are wrong in arranging and planning strategies, one of the reasons for the failure of company businesses because the strategy formulation process in the company is not going well, Ali and Kodrat, (2017).

Kotler and Armstrong, (2012) state that behavior refers to the individual purchasing behavior of end consumers and households who buy goods or services for personal consumption. Purchases made by consumers are actions taken on the basis of fulfilling needs, so that social media big parties for business actors to market their products to consumers, which can be used for advertising and bringing consumers together with a product and awareness, of course not only to entertain, but to provide information to consumers about this matter. Pudjihardjo and Wijaya, (2015) concluded that online purchasing decisions were seen from the influence of the dimensions of trust, information quality, and product appearance.

The use of technology such as social media is currently very important for business growth, so that it can provide added value for consumers because social media as an Integrated Marketing Communication (IMC) is able to provide a competitive advantage for business people. At least business actors can communicate with old customers and attract new customers so that SMEs can survive in the midst of competition, Siswanto, T. (2013). With the use of media it is also felt that it can cut a series of consumer actions in buying a product, so that in determining and planning a strategy, consumer understanding must also be considered because it is appropriate. 
So this study aims to analyze the influence of social media users on purchasing decisions in small and medium enterprises in Pontianak City.

\section{Literature Review}

This research was conducted in 2020 and tries to increase the influence of social media users on purchasing decisions, in which social media can be used as a reliable tool between users. In using social media and using it as something new for media marketing, many companies and business actors are able to build relationships and reach consumers more effectively. Social media marketing that companies use as a tool for their marketing activities is centered on dimensions: Online Community, Interaction, Content Sharing, and credibility, As'ad, H. A and Anas, Y. A, (2014).

Online Community: A company or business can use social media to build a community around its product or business. Working communities create loyalty and foster discussion, which can contribute to increased business, Taprial, and Kanwar (2012). Marketing through social media, by building online communities, is felt to be able to create and encourage discussion with consumers and create relationships in providing emotionally binding messages. Based on this description, the hypothesis in this study is $\mathrm{H} 1=$ Online Community has a positive effect on Social Media.

Interaction: networking sites allow greater interaction with online communities through broadcasting the latest information relevant to consumers, Fischer, and Reuber, (2011). So it can be said that media interaction is an advertising activity carried out to provide relevant information and an invitation for consumers to provide and provide a good experience. Based on this description, the hypothesis in this study is $\mathrm{H} 2=$ Interaction has a positive effect on social media.

Sharing of Content: Dimensions are about the extent to which a person changes, shares and accepts content in social media settings. Babac, (2011). The can be said " Content is the way to do change in order in a product by consumers based on their needs or tastes through social media. Based on this description, the hypothesis in this study is that $\mathrm{H} 3=$ Sharing of content has a positive effect on Social Media.

Accessibility: Social media is easily accessible and requires minimal or no fees to use. Social media is easy to use and does not require special skills, knowledge to use. Taprial, and Kanwar, (2012) Therefore, it is important to provide benefits to consumers from all possible aspects to create added value for business actors. Based on this description, the hypothesis in this study is $\mathrm{H} 4=$ has a positive effect on social media.

Credibility: In creating good value in order to connect directly and generate trust in consumers, business actors need to have credibility that reflects the responsibilities of business actors and motivates and generates loyal customers. It's about getting your message across clearly to people, building credibility for what you say or do, connecting emotionally with your target audience, motivating buyers, and generating loyal customers. Social media provides an excellent platform for all businesses (big or small) to network and reach their target audience, connect with them directly and generate trust by listening to what they have to say. Taprial, and Kanwar, (2012). Based on this description, the hypothesis in this study is $\mathrm{H} 5=$ Credibility has a positive effect on social media.

Social media: Social media provides an excellent platform for all businesses (big or small) to network and reach their target audience, connect with them directly and generate trust by listening to what they have to say. Taprial, and Kanwar, (2012). Social media applications that display sharing of photos or images that are proven to have a strong display in influencing consumer buying interest Indika, Jovita, (2017). Persuasive messages will be more effective when we know that the messenger is an expert. provided in their field according to Azwar, (2011). So it can be said that the use of social media is a strategy that can be used to influence consumer decisions in making purchases. Based on this description, the hypothesis in this study is $\mathrm{H} 6=$ Social media has a positive effect on purchasing decisions.

Purchase decisions: Consumer purchasing decisions are actually a collection of a number of decisions on the type of product, form of product, brand, seller, number of products, time of purchase, and method of payment Priansa, (2017). Therefore, the importance of understanding consumers must also pay attention to the use of social media to reduce consumer action in purchasing a product, so that they are able to determine and plan an appropriate strategy, in line with Kotler and Armstrong (2012), which states that actually buying is not only is a single action (for example because of a product), but consists of several related actions. Based on this description, the hypothesis in this study is $\mathrm{H} 7$ = Marketing dimensions have an indirect effect on purchasing decisions through social media as an intervening variable. 
In this study also, several previous studies were used as a basis such as A. Setiadi (2016) which stated that the Benefits of Social Media in the Effectiveness of Integrated Marketing Communications such as socialization and interaction, networking sites, Integrated Marketing Communication (IMC) and Two-Way Communication. The phenomenon of the presence of social media as a result of the development of information and communication technology is indeed extraordinary. With a variety of services that can be used, social media has changed the way of communicating in society. The presence of social media has an impact on ways of communication in all fields, such as marketing communication, political communication and communication in the learning system, besides Irianto, (2015) also concluded that the use of social media can improve the image of a brand, this can be used by MSMEs to introducing, developing and maintaining its brand. Furthermore, according to Pudjihardjo and Wijaya, (2015) concluded that online purchasing decisions seen from the influence of the dimensions of trust, convenience, information quality, and product display simultaneously have a significant effect on purchasing decisions through marketing on social media.

\section{Research Method}

Used is explanatory research, by making 100 consumers who make purchases via social media from SMEs in Pontianak City as respondents, using the Accidental Simple Random Sampling method. The type of data used is quantitative data, which is obtained from a questionnaire that has been compiled and developed from previous research related to operational variables, as a data collection tool. This study is based on the types of social media based on the social media platforms that are most loved by Indonesians, including YouTube, Facebook, WhatsApp, Instagram (Hootsuite). The results of the questionnaires that were filled in were tabulated and then processed using Structural Equation Modelling (SEM) through the IBM Amos v26 program. This study uses descriptive analysis based on the results of data processing to clearly describe the influence of social media users on purchasing decisions of SMEs in Pontianak City. Through data respondents or questionnaires, schematically the research framework can be described as follows:

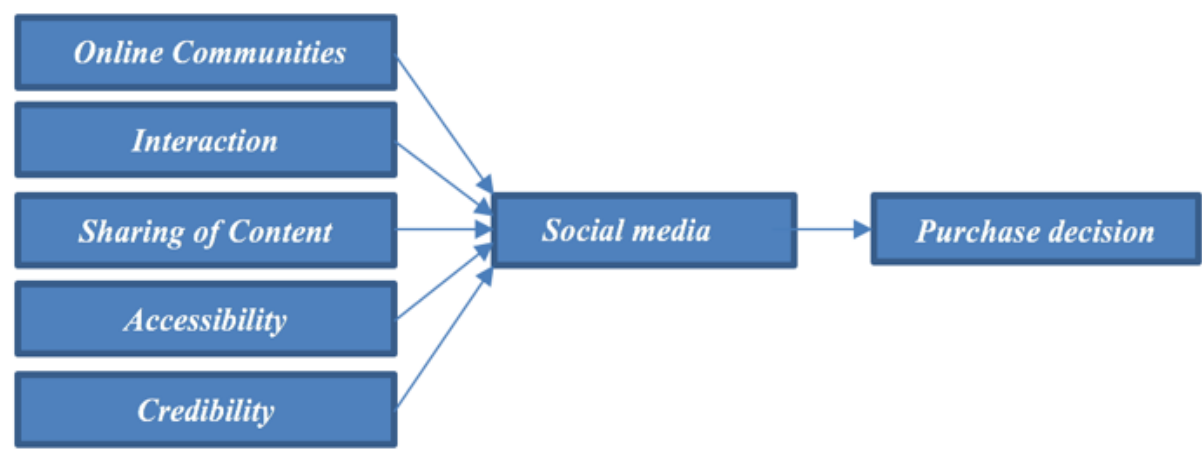

Figure 1. Research framework

Result

Based on the answers given by the survey results in this study, are shown in the table as follows:

Table 2. Social media used

\begin{tabular}{|c|c|c|c|}
\hline Youtube & FaceBook & WhatsApp & Instragram \\
\hline $7 \%$ & $8 \%$ & $28 \%$ & $57 \%$ \\
\hline
\end{tabular}

According to the data in table from the social media used by respondents in their purchase decisions, Youtube reached $7 \%$, followed by WhatsApp $8 \%$, Facebook $28 \%$, and Instagram $57 \%$. So it can be said that current social media users, both business people and consumers, provide opportunities as a new strategy in marketing a product or service, especially on the Instagram application. 
Tabel 3. Index Goodness of Fit

\begin{tabular}{|l|c|c|c|}
\hline \multicolumn{1}{|c|}{ Goodness of index } & Estimate & Cut Off Value & Model \\
\hline Chi-square & 2,317 & Small & Acceptable Fit \\
\hline Probability & 0,678 & $\geq 0,05$ & Good fit \\
\hline RMSEA & 0,000 & $\leq 0,08$ & Good fit \\
\hline GFI & 0,993 & $\geq 0,90$ & Good fit \\
\hline AGFI & 0,954 & $\geq 0,90$ & Good fit \\
\hline CMIN/DF & 0,579 & $\leq 2,00$ & Good fit \\
\hline TLI & 1,012 & $\geq 0,95$ & Good fit \\
\hline CFI & 1,000 & $\geq 0,95$ & Good fit \\
\hline NFI & 0,997 & $\geq 0,90$ & Good fit \\
\hline
\end{tabular}

Source: Results of the research Output AMOS, 2020

Based on the output from the calculations carried out, the index goodness obtained by the Chi-square value is 2,317 with a p-value of 0.678 which is greater than the value of $a=5 \%$, it can be said that the model is fit. In addition, the Feasibility Test Index for the GFI Model $=0.993, \mathrm{AGFI}=0.954, \mathrm{TLI}=1.012$, and $\mathrm{CFI}=1,000$ where the value generated by GFI is $\geq 0.90$, and TLI $\geq 0.95$, so it can be said that the model is suitable. The CMIN/DF value of 0.579 obtained has a value greater than $\leq 2.00$ so that it can be said that the model is fit and the RMSEA value is 0,000 where the value is less than $\leq 0.8$ so that the model can be said to be fit. The results of the test model that shows the goodness of fit to the data can be described as follows:

Figure 2. AMOS Program Output
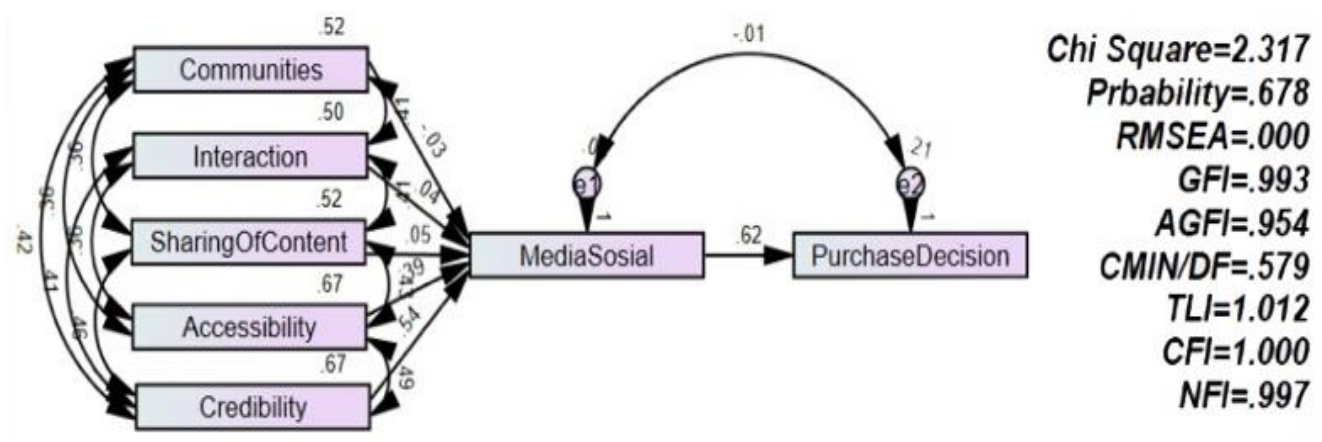

Source: Results of the research Output AMOS, 2020

The output model in the image above, was carried out by looking at the significant level between the relationship of each variable seen through the critical ratio (cr) and the significance probability value of each variable in the form of Regression Weight output.

Table 4. Regression Weights: (Group number 1 - Default model)

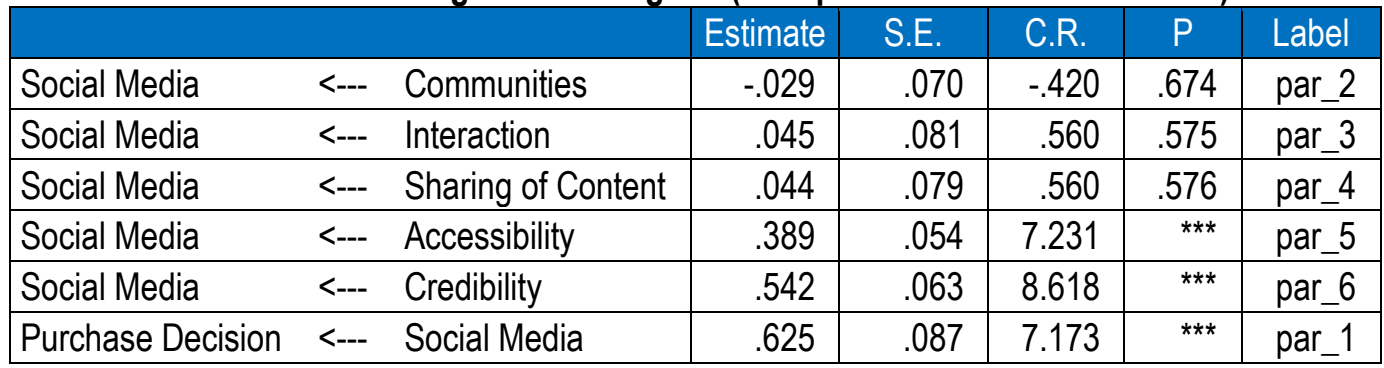

Source: Outout AMOS test result, 2020 
From the table above it can be seen that, testing can be done by looking at the value of the $P$ value if it has a very small value $\left.{ }^{* * *}=0.000\right)$ and is below 0.05 then It can be said that there is an influence and the hypothesis is acceptable. It is known that for the first hypothesis a P value of $0.674>0.05$ was obtained, then $\mathrm{H} 1$ was rejected, so it could be concluded that Online Communities had no effect on social media. The results of the second hypothesis test obtained $\mathrm{P}$ value $0.575>0.05$ then $\mathrm{H} 2$ is rejected, so it can be concluded that the interaction has no effect on social media. The result of testing the third hypothesis shows that $P$ value $0.576>$ 0.05 then $\mathrm{H} 3$ is rejected, so it can be concluded that Sharing of Content has no effect on social media. The fourth hypothesis gets a $\mathrm{P}$ value of $0.000<0.05$, then $\mathrm{H} 4$ is accepted, so it can be concluded that accessibility has an effect on social media. The results obtained for the fifth hypothesis are $\mathrm{P}$ value $0.000<0.05$, then $\mathrm{H} 5$ is accepted, so it can be concluded that credibility has an effect on social media. The results for the sixth hypothesis are seen from the $\mathrm{P}$ value $0.000<0.05$ then $\mathrm{H} 5$ is accepted, so it can be concluded that social media has an influence on purchasing decisions.

Meanwhile, to find out the results of the formulation of the seven hypotheses, direct and indirect relationships can be seen in the Standardized total effect table, standardized direct effect, and standardized indirect effect.

Table 5. Standardized Total Effects (Group number 1 - Default model)

\begin{tabular}{|l|c|c|c|c|c|c|}
\hline & Credibility & Accessibility & Sharing of Content & Interaction & Communities & Social Media \\
\hline Social Media & .575 & .413 & .041 & .041 & -.027 & .000 \\
\hline Purchase Decision & .422 & .303 & .030 & .030 & -.020 & .734 \\
\hline
\end{tabular}

Source: AMOS test result, 2020

Table 6. Standardized Direct Effects (Group number 1 - Default model) \begin{tabular}{|l|l|l|l|l|l|} 
Credibility & Accessibility & Sharing of Content & Interaction Communities & Social Media
\end{tabular}

\begin{tabular}{|l|c|c|c|c|c|c|}
\hline & Credibility & Accessibility & Sharing of Content & Interaction & Communities & Social Media \\
\hline Social Media & .575 & .413 & .041 & .041 & -.027 & .000 \\
\hline Purchase Decision & .000 & .000 & .000 & .000 & .000 & .734 \\
\hline
\end{tabular}

Source: AMOS test result, 2020

Table 7. Standardized Indirect Effects (Group number 1 - Default model)

\begin{tabular}{|l|c|c|c|c|c|c|}
\hline & Credibility & Accessibility & Sharing of Content & Interaction & Communities & Social Media \\
\hline Social Media & .000 & .000 & .000 & .000 & .000 & .000 \\
\hline Purchase Decision & .422 & .303 & .030 & .030 & -.020 & .000 \\
\hline
\end{tabular}

Source: AMOS test result, 2020

When compared with the indirect effect table for direct or indirect influence between Communities, Interaction, Sharing of Content, Credibility, Accessibility, on Purchase Decisions through social media. In simple terms, namely by comparing the value of the direct effect is greater than the indirect effect, so it can be said that $\mathrm{H} 7$ is rejected, where the Marketing Dimension has no indirect effect on purchasing decisions through social media as an intervening variable.

\section{Discussion}

The importance of determining a permanent strategy to market a product or service by utilizing current technology is a determining factor in running a business. With social media that is able to make many people connected, making it easier to access information, so that social media can also be used as an effective marketing medium because social media has the ability to reach a wide audience. Sheldon and Newman, (2019) Instagram is the social media with the fastest growing number of users, so many online news providers are looking for their market there. Not a few business people use social media such as Instagram as a means of promotion because the costs are relatively cheap and easy to use, so that more business people are competing to use Instagram which can provide more benefits. Alfajii. F. A, Viranda. A, and Qurrotul. A, (2019) The use of social media analytics on Instagram, namely the presence of insight features has an important role in helping users, especially business people, in increasing the effectiveness of marketing their products and services.

The absence of an online community, which is one of the dimensions of marketing through social media, has made the low relationship between social media users in SMEs in creating and encouraging discussions with consumers, so that they have not been able to create relationships in providing messages that can tie 
emotionally to social media users. According to Kotler and Keller (2012), online communities and forums are formed by a group of consumers and a group of members who have the influence of advertising and a collection of companies or support from companies where members who are members of the online community can communicate with the company and other members through posts, messages instant, and chat discussions about special interests related to the product and brand. The use in the use of media for a business, especially in SMEs in Pontianak City, is something that is deemed necessary considering that the number of social media users provides opportunities for the development of a business, which according to Taprial and Kanwar, (2012) A company or business can use social media for build a community around the product or business. A working community creates loyalty and encourages discussion development, which can contribute to business growth.

Interaction as an action that leads to something through social media as an exchange or activity carried out by consumers at SMEs in Pontianak City currently has not shown the relevance of social media in inviting consumers to provide and provide good experiences. Meanwhile, according to Fischer, E. and Reuber, R. (2011), social networking sites allow greater interaction with online communities through broadcasting the latest information relevant to consumers, while according to Putri, (2017), The disadvantage of advertising is that it does not interact directly with buyers and may not attract customer attention.

The use of social media in SMEs in the city of Pontianak have not been able to create changes in the arrangement of their products to consumers based on their needs or tastes through dimensions. Sharing of Content so that it has not been able to create changes in the arrangement of its products to consumers based on their needs or tastes through social media, Babac, R. (2011). Sharing of Content is about the extent to which a person changes, changes, and accepts content in social media settings. According to Juditha, C. (2017), the high penetration of social media also provides opportunities for producers to produce products or services through social media, so that the ability to create content that can attract attention and represent consumers by utilizing social media to share it has the opportunity to get noticed and be able to be remembered by consumers.

In providing services to obtain information, SMEs in Pontianak City have done well so that they have a positive influence on the social media of business actors, according to As'ad, H. A and Anas Y. A, (2014) the importance of the dimensions of marketing media and for each. Each that, the most influential dimensions are accessibility and interaction with brand equity. Therefore, providing benefits to consumers from all possible aspects can create value for both customers and SMEs in Pontianak City.

Delivering messages clearly to consumers, in building credibility with words and actions that are emotionally connected to consumers, motivating buyers and generating loyal customers has been implemented well and has a positive impact on social media in SMEs in Pontianak City in line with what Taprial and Kanwar stated. , (2012) credibility is the creation of good value in order to connect directly and generate trust in consumers, business actors who need to have credibility that reflects the responsibilities of business actors and motivates and generates loyal customers. It's about getting your message across clearly to people, building credibility for what you say or do, connecting emotionally with your target audience, motivating buyers, and generating loyal customers. Social media provides an excellent platform for all businesses (big or small) to network and reach their target audience, connect with them directly and generate trust by listening to what they have to say, which according to Azwar, (2011) is a persuasive message. It will be more effective if we see that the messenger is an expert in his field.

Strategies for marketing a product or service through social media have a positive impact and influence on purchasing decisions. So that it can be used the use of social media to describe reality, as well as provide quick access to information in various content, be it writing, pictures, videos, and so on, in line with the results of research conducted by Rahman. M. A, (2016). Social media purchases have a positive effect on decisions via the internet. Andreas and Haenlein, (2010) define social media as a group of internet-based applications built on the foundation of Web 2.0 ideology and technology and support the exchange and exchange of user-generated content.

In total, it can be seen that the marketing dimension has a role in directly influencing purchasing decisions through social media, which according to which. Putri, C.S (2016) in her research that the indirect effect of social media on purchasing decisions is through buying interest, and the low purchasing decisions obtained by social media through purchase intention and other factors. So that social media can be said that social media is a means of providing information in implementing strategies in marketing a product, Moriansyah. (2015) concluded that social media is a marketing communication tool that can be categorized based on the reasons or motivations 
of marketers using social media (antecedents) and the target of the marketing program (consequences) that can be achieved using social media.

\section{Conclusion}

Based on the results of the study, it can be argued that the purchase decision made by consumers is an action of several alternatives offered, both in terms of products and providers, while social media can be said to be one of the strategies in influencing decisions that affect consumers with a marketing dimension. The purpose of this study was to determine how strong the influence of user media is on purchasing decisions in small and medium enterprises in Pontianak City, so that the results of this study can provide additional insight and understanding of consumer behavior, also social media users in making purchase decisions. The results of this study indicate that of the seven hypotheses formulated; There is a variable Online Community and Content Sharing that rejects the influence of social media, but it has no effect on social media, besides social media also has an influence on purchasing decisions, and over all it can be said that the Marketing Dimensions directly influence purchasing decisions through social media.

Suggestions for small and medium enterprises in Pontianak City are expected to continue to innovate and develop their business by making creative and innovative strategies in creating buying interest that can indirectly influence purchasing decisions made by consumers through social media, as well as building good relationships. Towards consumers by forming a community so that the community can share with each other the ability, knowledge, information that is trending, so that they can move together. Interactive communication so as to build mutual trust, exchange ideas and arguments, and share information that can attract consumer attention.

\section{References}

A. Setiadi. (2016). "Pemanfaatan Media Sosial Untuk Efektifitas Komunikasi, Jurnal Humaniora", Unversitas Bina Sarana Informatika, Vol. 16, No. 2.

A.B.P, Irianto. (2015). "Pemanfaatan Sosial Media Untuk Meningkatkan Market Share UKM", Teknomatika Vol. 8, No. 1.

Alfajri. F. A, Viranda. A, \& Qurrotul. A. (2019). Pemanfaatan Social Media Analytics pada Instagram Dalam Peningkatan Efektivitas Pemasaran. Interaksi: Jurnal IImu Komunikasi. ISSN 2310-605, ISSN 25484907, Vol. 8, No. 2, pp.1-11.

As'ad, H. A dan Anas Y. A. (2014). The Impact of Social Media Marketing on Brand Equity: An Empirical Study on Mobile Service Providers in Jordan. Society of Interdisciplinary Business Research, Vol 3 No.1, 315326

Azwar S. (2011). Sikap Manusia: Teori dan Pengukurannya. Pustaka, Jakarta.

Babac, R. (2011). "Impact of Social Media Use on Brand Equity of Magazine Brands", Halmstad University, Sweden.

D. J. Priansa. (2017). Perilaku Konsumen Dalam Persaingan Bisnis Kontemporer. Alfabeta, Bandung.

D. R. Indika dan C. Jovita. (2017). Media Sosial Instagram Sebagai Sarana Promosi Untuk Meningkatkan Minat Beli Konsumen. Jurnal Bisnis Terapan, Vol. 01, No. 01.

Dwianto, A. G., Iqbal, M., \& Alfisyahr, R. (2018). Analisis Dampak Pemasaran di Media Sosial Online terhadap Citra Merek, Mlnat Beli Knsumen dan Net Promoter Score | Pendekatan Eksperimental Virtual Brand Following pada aplikasi Instagram produk Fast Moving Consumer Goods @ erigostore pada Mahasiswa S. Jurnal Administrasi Bisnis (JAB), 55.1, 91-99.

Fischer, E. \& Reuber, R. (2011). Social interaction via new social media: (How) can interactions on Twitter affect effectual thinking and behavior?. Journal of Business Venturing, (26), PP. 3-21.

Hootsuite (We are Social). (2020). The Essential Headline Data You Need To Understand The State Of Mobile, Internet, And Social Media Use.

Juditha, C. (2017). Understanding Social Media Network Structure as a Strategic Way of Advertising in Digital Economy Era. Jurnal Pekommas, Jakarta. Vol. 2 No. 1, April 2017: 99-114.

Sheldon, P., \& Newman, M. (2019). Instagram and American Teens: Understanding Motives for Its Use and Relationship to Excessive Reassurance-Seeking and Interpersonal Rejection. The Journal of Social Media in Society, 8(1), 1-16.

Kotler, Philip and Gary Amstrong. (2012). Principles Of Marketing. Global Edition, Perason Education.

Kotler, Keller. (2012). Marketing Management (14 thed). United State: Pearson. 
L. Moriansyah. (2015). Pemasaran Melalui Media Sosial: Antecedents Dan Consequences: Sosial Media Marketing: Antecedents And Consequences. Jurnal Penelitian Komunikasi dan Opini Publik Vol. 19 No.3: 187-196.

M.C, Pudjihardjo, H. Wijaya. (2015). Analisa Pengaruh Kepercayaan, Kemudahan, Kualitas Informasi, Dan Tampilan Produk Terhadap Keputusan Pembelian Melalui Pemasaran Di Media Sosial (Studi Pada Pengguna Media Sosial Di Shapeharve). Jurnal Hospitality dan Manajemen Jasa, Vol 3, No 2.

M.Y. Ali, D.S. Kodrat. (2017). Faktor-Faktor Penyebab Kegagalan Bisnis Pada Perusahaan Mitra Jaya Abadi. Performa: Jurnal Manajemen dan Start-Up Bisnis Vol 2, No 1.

Purwaningwulan. M.M. (2012). Daya Tarik Pesan Iklan Humor. Jurnal Majalah Ilmiah Unikom, Vol. 10, No. 1.

Putri. B.R.T. (2017) .Manajemen Pemasaran, F. Peternakan, Universitas Udayana.

Putri, C. S. (2016). Pengaruh Media Sosial Terhadap Keputusan Pembelian Konsumen Cherie Melalui Minat Beli. PERFORMA: Jurnal Manajemen dan Start-Up Bisnis. Volume 1, Nomor 5.

Rahman. M. A. (2016). Pengaruh Penggunaan Media Sosial Terhadap Keputusan Pembelian Lewat Internet di Kalangan Mahasiswa. Asset: Jurnal Ekonomi, Manajemen, dan Akutansi, Vol 6, No. 1.

S. Wulandari, N.A. Supratman. (2018). Potensi Penggunaan Media Sosial Bagi UKM, Performa: Media IImiah Teknik Industri, Vol. 17, No.1: 14-23.

T. Siwanto. (2013). Optimalisasi Sosial Media Sebagai Media Pemasaran Usaha Kecil Menengah. Jurnal Liquidity, Vol 2, No.1.

Taprial, V. \& Kanwar, P. (2012). Understanding Social Media. United States: Ventus Publishing. 